\title{
TAPHONOMIC BIASES AND ENVIRONMENTAL DIFFERENCES AMONG NORTH AMERICAN SILURIAN KONSERVAT LAGERSTÄTTEN
}

KLUESSENDORF*, Joanne, Museum of Natural History and Department of Geology, University of Illinois, 1301 W. Green St., Urbana, IL 61801, U. S. A.; MIKULIC, Donald G., Illinois State Geological Survey, 615 E. Peabody Dr., Champaign, IL 61820, U. S. A.

As demonstrated by Silurian Konservat Lagerstätten from North America, not all Lagerstätten represent living associations but are biased taphonomically, and the conditions necessary for exceptional preservation are environmentally, temporally, and areally diverse.

The early Silurian (late Llandovery-early Wenlock; Brandon Bridge strata) Lagerstätte from Waukesha, Wisconsin, was deposited under peritidal conditions in a thin, narrow zone adjacent to a karst-formed paleoscarp during transgression. Anoxic conditions resulting from restricted circulation and eutrophication are indicated by sediment lamination, shell decalcification, absence of sessile benthos, coiling of worms, absence of Chondrites (ubiquitous elsewhere), and presence of Pacytheca alga. Although anoxia, which was neither widespread nor long-lived, excluded most benthonic organisms, arthropods are abundant and diverse. These are mainly exuviae as suggested by consistent lack of specific body parts, extreme compaction, monotaxic size-sorted assemblages, absence of trackways and escape traces, and absence of enrollment in response to anoxia. This then is not a living association, but a taphonomic accumulation of mostly arthropod exuviae that were concentrated hydrodynamically.

Arthropods (mainly eurypterids and phyllocariids) dominate late Silurian (LudlowPridoli; various units) Lagerstätten that were deposited in hypersaline peritidal lagoons surrounding the Michigan Basin in the U.S. and Canada. Although less diverse, these biotas were more widely distributed and of longer duration than the Waukesha Lagerstätte. Hypersalinity inhibited bacterial decomposition and lowered oxygen solubility, further excluding benthos by creating interstitial anoxia. These compose another example of taphonomically biased Lagerstätten, consisting chiefly of arthropod exuviae.

The late Silurian (Ludlow, Racine Dolomite) Lecthaylus Lagerstätte was deposited in deeper water on the shelf or slope of the Michigan Basin in northeastern Illinois. The limited biota, dominated by a single worm taxon (Lecthaylus) includes phyllocariids, graptolites and inarticulate brachiopods. Worms are outstretched and grouped in an orientation that suggests in situ burial. Laminated strata are succeeded by bioturbated sediment in cyclic repetition, indicating recolonization by wormlike burrowers (Lecthaylus?) following rapid sediment influx and burial of the biota under interstitial anoxic conditions. This is probably an autochthonous biota; sessile benthonic organisms may be absent as a result of soft substrate consistency or high sedimentation rate.

These Silurian Lagerstätten show that anoxia required for early diagenetic mineralization and exceptional preservation may be established in different amounts of time and in various ways (stagnant sediment trap, hypersalinity, obrution) and settings from peritidal to shelf/slope. Identification of these variations is important for prediction of additional Lagerstätten sites. Although arthropods in exuviae-dominated Lagerstätten may accurately reflect their true taxonomic diversity, they are probably present in greater numbers and in higher dominance relative to other taxa than in living associations. 